\title{
Determinations of Minerals Composition of Rices in Java Island, Indonesia
}

\author{
Endah DAMASTUTI, Syukria KuRNIAWATI, Woro Yatu Niken SYAHFITRI, \\ Natalia Adventini, Diah Dwiana LESTIANI and Muhayatun SANTOSO \\ Center for Applied Nuclear Science and Technology, National Nuclear Energy Agency, \\ Bandung 40132, Indonesia
}

(Received June 26, 2019)

\begin{abstract}
Summary Rice (Oryza sativa L.) is one of the staple foods widely consumed by Indonesian people. They usually have rice as the biggest portion on their diet, therefore rice becomes the main source of nutrients of Indonesian people mainly for those whom live in Java Islands. Although rice is known to contain various minerals, but the minerals level are varied based on differences in geographic region associated with soil quality. Hence, quantity and quality of minerals content of rice from different regions of the world are particularly important to be characterized. The present aim of the study was to assess the composition of mineral of rice from different geographical regions in Java Islands, Indonesia using nuclear analytical techniques i.e. Neutron Activation Analysis method... Quality control of data analysis was assessed using SRM NIST Rice Flour 1568a and gave good results with accuracy ( $\%$ bias) $\leq 5 \%$ and precision $(\% \mathrm{CV}$ ) less than $10 \%$. The essential elements contents such as Fe, Zn, and Se were quantified and found in the range of 2.8-60.9, 2.48-28.8, and $0.01-2.17 \mathrm{mg} / \mathrm{kg}$ respectively, while for the toxic elements, $\mathrm{Cr}$ and Co in rice are also quantified and found in the range of $0.03-1.24$ and $0.003-0.59 \mathrm{mg} / \mathrm{kg}$, respectivelyThe elemental concentrations in rices from Java Island followed the order $\mathrm{Zn}>\mathrm{Fe}>\mathrm{Se}>\mathrm{Cr}>\mathrm{Co}$. It also found that rices from East Java Province have higher concentrations of $\mathrm{Fe}$ and Se, while the highest mean of $\mathrm{Zn}$ concentration was found in the rices from Jakarta province. The daily intake of those elements in rices give significant contribution to their RDA values. These results of mineral contents in rice hopefully can be used as one of references for estimating daily nutritional intake status of especially Javanese people.
\end{abstract}

Key Words rice, nutrient, element, daily intake

Rice (Oryza sativa L.) is one of the most consumed cereals in the world and is the staple food for more than half of the world's human population, especially in Asian countries including in Indonesia. Rice is a good source of carbohydrates, thiamin, vitamin B6 and other nutrients such as essential elements of mineral like Magnesium, Iron, Zinc and also toxic elements as well (1-4). In Indonesia, rice is one of the staple foods widely consumed by Indonesian people and also widely grown in Indonesia. From Rice Market Monitor (RMM) by Food and Agriculture Organization of the United Nations (FAO), Indonesia is considered as one of fives biggest rice production and Java Island placed as the main production of rice as well as consumption according to Statistics Indonesia (BPS), 2012. Since rice is consumed as the main ingredient in Indonesian diet, the nutrient composition especially mineral elements in rice is great importance in relation to its nutritional value assessment. Several researches related with the mineral composition has been carried out. Mulyaningsih, 2009 has been found the Iron and Zinc contents in rices from Banten were lower than $50 \mathrm{mg} / \mathrm{kg}$ (5), while Rohaeni, 2016 were found that the highest concentration of Iron

E-mail: endah_dt@batan.go.id in several milled rices from West Java was $12.25 \mathrm{mg} . \mathrm{kg}$, while for the highest concentration of Zn was 26.35 $\mathrm{mg} / \mathrm{kg}$ (6). Element contents of Thai jasmine rice were also determined by Seeprasert (2), and found that the elemental concentrations in rice followed the order $\mathrm{K}>\mathrm{Zn}>\mathrm{Mn}$.

Mineral is chemical elements required in a small amount as essential nutrient by human body to perform functions needed for life. These include the formation of bones and teeth; as essential constituents of body fluids and tissues; as components of enzyme systems and for normal nerve function (7). The five major minerals in the human body e.g. calcium, phosphorus, potassium, sodium, and magnesium are needed in larger amount than others. Others are required in smaller quantities and are sometimes called trace elements $(8,9)$. The trace elements that have a specific biochemical function in the human body are sulfur, iron, chlorine, cobalt, copper, zinc, manganese, molybdenum, iodine and selenium. The importance of trace elements in nutrition is widely recognized as essential for growth and development of human beings (8). They are also having an important role in biological systems by taking part in numerous biochemical processes in the human body $(7$, 10). However, the essentiality of such elements is valid 


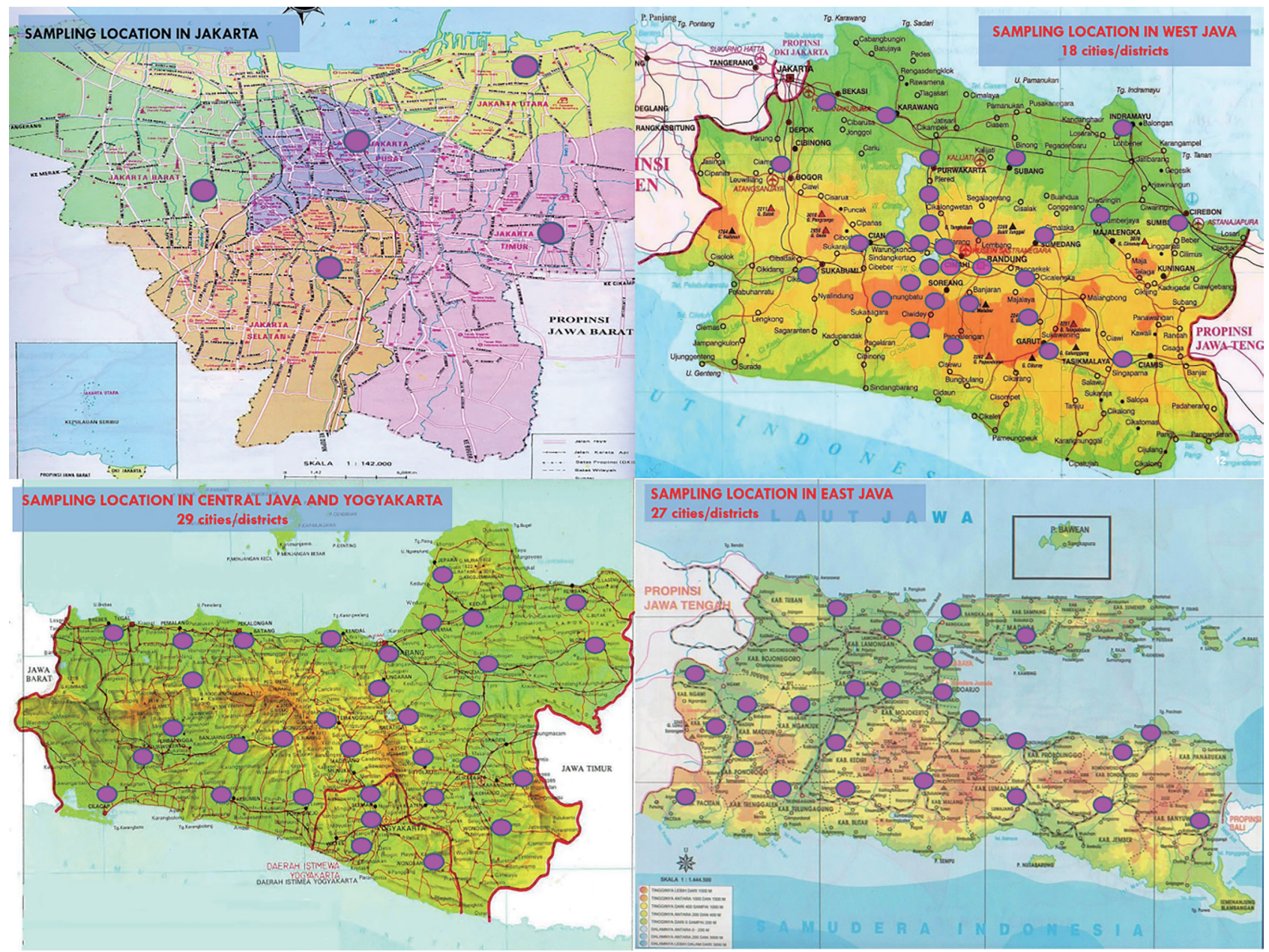

Fig. 1. Sampling locations.

only at certain levels of concentration. At higher level, they become toxic, while at lower concentration, they result in deficiency (11). Some diseases are clearly correlated with an imbalance of trace elements in the human body $(8)$. The excess or deficiency of some trace elements has a significant influence on human health $(7,11)$. Major entry of these elements into the body is through diet. They are often absorbed more efficiently by the body if supplied in foods rather than as supplements.

Minerals composition in rice as listed in Indonesian Food composition table 2009 is still unsufficient and obsolete. They were taken from researches conducted in around 1950-1960 and with limited number of the samples. Some of them are also adopted from nutrient data in other countries (10). This matter may lead to the false conclusion or estimation related with the nutritional status of Indonesian people. Therefore, the composition of the essential mineral content in rice will be a valuable information for the database of Indonesian Food Composition Table and for human dietary intake needed by nutritionists. Several analytical methods have been used by several researches in the world to obtain the nutrient composition in food. Several methods, such as atomic absorption spectrometry (AAS) whether Flame-AAS or Electro Thermal-AAS (1, 4,
12-14), inductively coupled plasma atomic emission spectroscopy (ICPAES) $(15,16)$ and inductively coupled plasma mass spectrometry (ICPMS) $(3,11)$ are commonly used for elemental analysis in rice samples by several countries. However, analytical methods such as AAS, ICP-OES and ICP-MS have several disadvantages. Those methods required samples destruction prior to analysis, which may lead to possibility contamination from the reagents used. Atomic absorption spectrometry (AAS) and ICP- OES only allowed single-element analysis that made them less efficient in time (2). Neutron activation analysis (NAA is known very suitable for multi-element analysis and is non- destructive. It has high sensitivity and selectivity with a very low detection limits that make NAA is usefull for determination of nutrient composition in rice, especially Se whose concentrations are small in the food samples (2). On previous activity, we have obtained some mineral composition in rices from West Java area e.g. Fe, $\mathrm{Zn}, \mathrm{Cr}$, Co and $\mathrm{Se}(10)$, however to obtain more reliable results of mineral composition in rice and known the variety of the elemental content of rices from Java Island, we have expanded the scope of the rices sampling in Central Java and also East Java to be characterized. This research was aimed to get information related to the minerals composition in rices from Java islands and know the 
Table 1. Quality control assesment using SRM NIST 1567a Wheat Flour (WF).

\begin{tabular}{lcccrc}
\hline Element & SRM & Result & $\begin{array}{c}\text { Certified } \\
\text { value }\end{array}$ & \%Rec & $\% \mathrm{CV}$ \\
\hline Co & WF & $0.018 \pm 0.001$ & 0.018 & 102 & 5 \\
Fe & WF & $7.40 \pm 0.49$ & $7.35 \pm 0.60$ & 99 & 1 \\
Mn & WF & $5.87 \pm 0.17$ & $5.75 \pm 0.17$ & 102 & 3 \\
Se & WF & $0.38 \pm 0.04$ & $0.36 \pm 0.03$ & 95 & 9 \\
Zn & WF & $11.9 \pm 0.50$ & $11.6 \pm 0.4$ & 103 & 4 \\
\hline
\end{tabular}

variety of the compositions of rices throughout Java Island so it can be used as references for nutritionists to estimate the daily nutrient intake of rices for local inhabitant more accurately.

\section{MATERIALS AND METHODS}

Materials. Standard reference materials Rice Fluor (SRM 1568a) was obtained from the National Institute of Standards and Technology, demineralization water $\left(>18 \mathrm{M} \Omega \mathrm{cm}^{2}\right)$ was used throughout this work, the multi-elements standard solution (ICP E-Merck), tritisol standard solution (E-Merck) and polyethylene vials.

Sample design and collections. The rice taken are consist of various type of white rices such as IR, Jembar, Setra, Kurmo and Pandan Wangi. These types of rice are commonly consumed by Javanese people.. The rice was collected from several traditional market in 68 cities/ districts in Java Island. As much as 89 white rice samples were collected. Each rice samples were taken as much as $1 \mathrm{~kg}$ and put in polyethylene bags. The location of sampling sites can be seen in Fig. 1.

Sample preparation and analysis. The rice samples were air-dried at room temperature, crushed to a homogeneous fine powder by titanium blade blender. The dried samples were grinded using mortar until the powder were homogenized and then oven-dried at $50-60^{\circ} \mathrm{C}$. About $50 \mathrm{mg}$ of each white rice sample were weighed and put into $0.3 \mathrm{~mL}$ polyethylene vial and then sealed by heating prior to neutron irradiation.

The analytical method used for quantified the elements was Neutron Activation Analysis. For this methods, standards were prepared from standard solution of ICP multi-elements standard solution VI E-Merck and consist of $1,1.01,10,10.2$ and $10 \mu \mathrm{g}$ of $\mathrm{Co}, \mathrm{Cr}, \mathrm{Fe}, \mathrm{Se}$ and $\mathrm{Zn}$ respectively, while as much as $10 \mu \mathrm{g}$ of each $\mathrm{Mn}$, and Ca were prepared by diluting E-Merck Tritisol standard solutions. Samples along with standard and SRM were then irradiated for $2 \mathrm{~h}$ for long half-life elements (Co, Cr, Fe, Se and Zn) at $15 \mathrm{MW}$ in rabbit system facilities of multipurpose reactor G.A. Siwabessy with thermal neutron flux of 1013 n.cm-2s-1. For analysis of $\mathrm{Co}, \mathrm{Cr}, \mathrm{Fe}, \mathrm{Se}$ and $\mathrm{Zn}$, samples then allowed to cooling for $2 \mathrm{wk}$ until one month then counted for $10000 \mathrm{~s}$ using gamma spectrometer with low resolution of HPGe detector. The resolution (FWHM) of the system was $1.90 \mathrm{keV}$ for $1332 \mathrm{keV}$ gamma-ray of $60 \mathrm{Co}$. The
Table 2. The concentration of essential minerals in white rice samples from Java island.

\begin{tabular}{|c|c|c|c|}
\hline \multirow{2}{*}{ Element } & \multicolumn{3}{|c|}{ Concentration ( $\mu \mathrm{g} / \mathrm{g}$, fresh weight) } \\
\hline & Min & Max & Mean \\
\hline Co & 0.003 & 0.59 & $0.08 \pm 0.07$ \\
\hline $\mathrm{Cr}$ & 0.03 & 1.24 & $0.16 \pm 0.17$ \\
\hline $\mathrm{Fe}$ & 2.81 & 60.91 & $10.78 \pm 7.50$ \\
\hline $\mathrm{Se}$ & 0.01 & 2.17 & $0.24 \pm 0.43$ \\
\hline $\mathrm{Zn}$ & 2.48 & 28.83 & $16.97 \pm 5.06$ \\
\hline
\end{tabular}

radionuclides measured were identified according to their half-lives and gamma-ray energies. The spectrum obtained was observed using Genie 2000 software at $1332.50 \mathrm{keV} ; 320.08 \mathrm{keV} ; 1099.25 \mathrm{keV} ; 264.66 \mathrm{keV}$ and $1115.52 \mathrm{keV}$ for $\mathrm{Co}, \mathrm{Cr}, \mathrm{Fe}$, Se and $\mathrm{Zn}$ respectively.

Quality control and assurance. For Quality control, as much as $50 \mathrm{mg}$ of SRM NIST 1568a Rice Flour were weighted and put in polythylene vials and irradiated along with samples using the same conditions of measurement as the samples, The standard reference material (SRM) was used as quality control assessment of data validity. The results of SRM observed were compared to its certificate values. The accuracy and precision of the analysis were evaluated by calculation of $\%$ recovery and $\% \mathrm{CV}$, respectively.

To assess the reliability of the result obtained and the accuracy of analytical methods used in this study, the standard reference material (SRM) which has similar to the matrix of sample, was also analyzed in the same conditions as the samples. The results of SRM NIST 1567a Wheat Flour for some elements were listed in Table 1. It is shown that the results obtained were in good agreement with its certified values. Analytical accuracy, described as\%recovery, were in the range 95-103\%; while analytical precision, described as $\% \mathrm{CV}$ were in the range $1-10 \%$. While for $\mathrm{Cr}$, since this element is not included in the certified quality assesment, its quality control was applied using traceable and certified ICP multi-element standard solution VI Certipur. Its accuracy and precission were found to be $96 \%$ and $9.7 \%$, respectively. All of analytical accuracy and precision were acceptable according to AOAC guidelines.

Data analysis. The information obtained from the gamma spectrum such as net areas of elements in samples and standards, counting time and counting duration were used to calculate the concentrations of the elements in the samples using a comparative method.

In this method, ICP standard that has the known mass value of elements (Wstd) and samples (Wspl) was irradiated simultaneously and was measured under the same counting conditions. The concentration of the elements in the sample is calculated by comparison of the measured activity between the samples $\left(\mathrm{A}_{0 \text { spl }}\right)$ and the ICP standard $\left(\mathrm{A}_{0 \mathrm{std}}\right)$, according to the following equation: 
Table 3. The concentration of $\mathrm{Fe}, \mathrm{Zn}, \mathrm{Se}, \mathrm{Co}$ and $\mathrm{Cr}$ of Rices from cities/districts in Java Island.

\begin{tabular}{|c|c|c|c|c|c|c|}
\hline \multirow{2}{*}{ No } & \multirow{2}{*}{ Cities/Districts } & \multicolumn{5}{|c|}{ Concentration (mg/kg) Wet Basis } \\
\hline & & $\mathrm{Fe}$ & $\mathrm{Zn}$ & $\mathrm{Se}$ & Co & $\mathrm{Cr}$ \\
\hline \multicolumn{7}{|c|}{ West Java (10) } \\
\hline 1 & Bekasi & $14.73 \pm 3.22$ & $19.50 \pm 0.36$ & $0.09 \pm 0.01$ & $0.09 \pm 0.01$ & $0.14 \pm 0.04$ \\
\hline 2 & Sukabumi & $7.39 \pm 1.69$ & $13.18 \pm 0.24$ & $0.11 \pm 0.01$ & $0.05 \pm 0.01$ & $0.12 \pm 0.01$ \\
\hline 3 & Indramayu & $12.91 \pm 1.87$ & $21.33 \pm 0.22$ & $0.07 \pm 0.02$ & $0.06 \pm 0.004$ & $0.11 \pm 0.02$ \\
\hline 4 & Cirebon & $10.30 \pm 1.93$ & $13.86 \pm 0.22$ & $<0.02$ & $0.07 \pm 0.005$ & $0.13 \pm 0.02$ \\
\hline 5 & Tasikmalaya & $<0.06$ & $14.26 \pm 0.38$ & $0.18 \pm 0.02$ & $0.06 \pm 0.007$ & $0.34 \pm 0.04$ \\
\hline 6 & Garut & $13.10 \pm 1.91$ & $16.20 \pm 0.23$ & $0.54 \pm 0.02$ & $0.09 \pm 0.004$ & $0.12 \pm 0.02$ \\
\hline 7 & Bogor & $4.12 \pm 0.54$ & $13.00 \pm 0.33$ & $<0.02$ & $0.00 \pm 0.0003$ & $0.12 \pm 0.01$ \\
\hline 8 & Karawang & $17.70 \pm 2.34$ & $22.96 \pm 0.30$ & $<0.02$ & $0.005 \pm 0.0002$ & $0.68 \pm 0.03$ \\
\hline 9 & Cianjur & $10.08 \pm 1.01$ & $12.35 \pm 0.12$ & $0.17 \pm 0.02$ & $0.13 \pm 0.003$ & $0.12 \pm 0.00$ \\
\hline 10 & Lembang & $6.62 \pm 1.21$ & $12.64 \pm 0.15$ & $0.16 \pm 0.02$ & $0.054 \pm 0.003$ & $0.08 \pm 0.00$ \\
\hline \multirow[t]{3}{*}{11} & Majalaya & $5.57 \pm 0.77$ & $8.67 \pm 0.17$ & $0.11 \pm 0.01$ & $0.032 \pm 0.003$ & $0.06 \pm 0.01$ \\
\hline & Mean & 10.25 & 15.27 & 0.18 & 0.06 & 0.18 \\
\hline & Range & $4.12-17.70$ & $8.67-22.96$ & $0.07-0.54$ & $0.003-0.13$ & $0.06-0.68$ \\
\hline Jaka & rta & & & & & \\
\hline 12 & Jakarta Utara & $4.80 \pm 1.70$ & $24.86 \pm 0.37$ & $0.07 \pm 0.02$ & $0.095 \pm 0.005$ & $0.11 \pm 0.02$ \\
\hline 13 & Jakarta Timur & $8.01 \pm 2.21$ & $20.87 \pm 0.36$ & $<0.02$ & $0.098 \pm 0.004$ & $0.07 \pm 0.01$ \\
\hline 14 & Jakarta Barat & $5.82 \pm 1.86$ & $23.39 \pm 0.39$ & $0.05 \pm 0.02$ & $0.092 \pm 0.005$ & $0.13 \pm 0.03$ \\
\hline 15 & Jakarta Selatan & $10.74 \pm 2.35$ & $22.97 \pm 0.21$ & $0.07 \pm 0.02$ & $0.091 \pm 0.003$ & $0.13 \pm 0.02$ \\
\hline 16 & Jakarta Pusat & $7.64 \pm 1.57$ & $18.41 \pm 0.17$ & $0.02 \pm 0.01$ & $0.076 \pm 0.003$ & $0.04 \pm 0.02$ \\
\hline & Mean & 7.40 & & 0.05 & 0.09 & 0.09 \\
\hline & Range & $4.80-10.74$ & $18.41-24.86$ & $0.02-0.07$ & $0.08-0.10$ & $0.04-0.13$ \\
\hline Cen & ral Java & & & & & \\
\hline 17 & Cilacap & $15.49 \pm 1.62$ & $10.15 \pm 0.12$ & $0.04 \pm 0.01$ & $0.176 \pm 0.006$ & $0.27 \pm 0.01$ \\
\hline 18 & Jepara & $8.66 \pm 1.00$ & $11.99 \pm 0.07$ & $1.20 \pm 0.02$ & $0.080 \pm 0.003$ & $0.07 \pm 0.01$ \\
\hline 19 & Purworejo & $8.57 \pm 0.90$ & $21.37 \pm 0.13$ & $0.06 \pm 0.01$ & $0.061 \pm 0.003$ & $0.18 \pm 0.01$ \\
\hline 20 & Pemalang & $7.10 \pm 0.97$ & $27.22 \pm 0.18$ & $0.03 \pm 0.01$ & $0.055 \pm 0.003$ & $0.27 \pm 0.00$ \\
\hline 21 & Pekalongan & $10.59 \pm 1.36$ & $20.27 \pm 0.16$ & $>0.02$ & $0.060 \pm 0.004$ & $0.33 \pm 0.01$ \\
\hline 22 & Kebumen & $14.91 \pm 1.02$ & $23.01 \pm 0.16$ & $0.04 \pm 0.01$ & $0.145 \pm 0.004$ & $0.21 \pm 0.01$ \\
\hline 23 & Demak & $9.06 \pm 1.06$ & $21.08 \pm 0.16$ & $0.07 \pm 0.01$ & $0.589 \pm 0.004$ & $0.27 \pm 0.01$ \\
\hline 24 & Kudus & $10.95 \pm 0.81$ & $16.98 \pm 0.12$ & $0.04 \pm 0.01$ & $0.08 \pm 0.00$ & $0.18 \pm 0.01$ \\
\hline 25 & Banyumas & $8.23 \pm 0.87$ & $17.99 \pm 0.11$ & $>0.02$ & $0.049 \pm 0.0026$ & $0.22 \pm 0.01$ \\
\hline 26 & Blora & $5.75 \pm 0.53$ & $8.14 \pm 0.10$ & $>0.02$ & $0.214 \pm 0.002$ & $1.24 \pm 0.01$ \\
\hline 27 & Magelang & $6.50 \pm 1.46$ & $20.78 \pm 0.22$ & $>0.02$ & $0.00 \pm 0.0001$ & $0.22 \pm 0.02$ \\
\hline 28 & Temanggung & $14.74 \pm 3.45$ & $18.41 \pm 0.54$ & $>0.02$ & $0.01 \pm 0.0004$ & $0.43 \pm 0.06$ \\
\hline 29 & Semarang & $6.31 \pm 1.99$ & $19.87 \pm 0.33$ & $>0.02$ & $0.01 \pm 0.0002$ & $0.11 \pm 0.03$ \\
\hline 30 & Karanganyar & $8.52 \pm 1.58$ & $15.19 \pm 0.20$ & $0.08 \pm 0.02$ & $0.01 \pm 0.0002$ & $0.18 \pm 0.03$ \\
\hline 31 & Pati & $9.83 \pm 1.25$ & $15.44 \pm 0.16$ & $>0.02$ & $0.005 \pm 0.0001$ & $0.23 \pm 0.02$ \\
\hline 32 & Rembang & $9.49 \pm 1.26$ & $15.10 \pm 0.16$ & $0.06 \pm 0.02$ & $0.00 \pm 0.0002$ & $0.32 \pm 0.02$ \\
\hline 33 & Brebes & $7.28 \pm 1.91$ & $17.02 \pm 0.27$ & $0.12 \pm 0.03$ & $0.10 \pm 0.0042$ & $0.09 \pm 0.02$ \\
\hline 34 & Wonosobo & $4.24 \pm 0.76$ & $17.05 \pm 0.19$ & $0.05 \pm 0.01$ & $0.094 \pm 0.003$ & $0.04 \pm 0.02$ \\
\hline 35 & Purbalingga & $2.81 \pm 0.94$ & $18.67 \pm 0.18$ & $0.11 \pm 0.02$ & $0.084 \pm 0.003$ & $0.04 \pm 0.02$ \\
\hline 36 & Wonogiri & $10.72 \pm 1.77$ & $16.79 \pm 0.27$ & $0.04 \pm 0.01$ & $0.10 \pm 0.004$ & $0.05 \pm 0.02$ \\
\hline 37 & Solo & $6.75 \pm 1.14$ & $17.79 \pm 0.22$ & $0.02 \pm 0.02$ & $0.098 \pm 0.003$ & $0.03 \pm 0.02$ \\
\hline 38 & Yogyakarta & $14.22 \pm 1.87$ & $13.64 \pm 0.25$ & $0.04 \pm 0.02$ & $0.09 \pm 0.004$ & $0.13 \pm 0.03$ \\
\hline 39 & Klaten & $<0.06$ & $12.38 \pm 0.13$ & $0.04 \pm 0.02$ & $0.082 \pm 0.003$ & $0.15 \pm 0.04$ \\
\hline 40 & Boyolali & $10.07 \pm 0.74$ & $2.48 \pm 0.07$ & $1.50 \pm 0.02$ & $0.068 \pm 0.002$ & $0.17 \pm 0.01$ \\
\hline 41 & Wonosari & $6.72 \pm 1.87$ & $12.03 \pm 0.18$ & $>0.02$ & $0.067 \pm 0.003$ & $0.10 \pm 0.02$ \\
\hline 42 & Bantul & $3.46 \pm 1.99$ & $14.41 \pm 0.19$ & $>0.02$ & $0.071 \pm 0.003$ & $0.08 \pm 0.04$ \\
\hline & Mean & 8.84 & 16.36 & 0.21 & 0.09 & 0.22 \\
\hline & Range & $2.81-15.49$ & $2.48-27.22$ & $0.02-1.50$ & $0.005-0.59$ & $0.03-1.24$ \\
\hline East & Java & & & & & \\
\hline 43 & Jombang & $11.65 \pm 1.20$ & $16.28 \pm 0.18$ & $>0.02$ & $0.057 \pm 0.003$ & $0.09 \pm 0.01$ \\
\hline 44 & Tuban & $7.22 \pm 1.63$ & $16.54 \pm 0.22$ & $0.06 \pm 0.02$ & $0.089 \pm 0.004$ & $0.05 \pm 0.02$ \\
\hline 45 & Gresik & $6.01 \pm 1.19$ & $14.79 \pm 0.21$ & $>0.02$ & $0.077 \pm 0.004$ & $0.04 \pm 0.01$ \\
\hline 46 & Sidoarjo & $7.69 \pm 1.16$ & $11.07 \pm 0.18$ & $>0.02$ & $0.053 \pm 0.003$ & $0.03 \pm 0.01$ \\
\hline 47 & Mojokerto & $14.32 \pm 1.38$ & $17.38 \pm 0.23$ & $0.05 \pm 0.02$ & $0.042 \pm 0.002$ & $0.07 \pm 0.02$ \\
\hline 48 & Lamongan & $4.62 \pm 1.02$ & $15.29 \pm 0.21$ & $0.06 \pm 0.02$ & $0.056 \pm 0.003$ & $0.04 \pm 0.01$ \\
\hline 49 & Bojonegoro & $9.25 \pm 1.33$ & $17.01 \pm 0.17$ & $0.04 \pm 0.01$ & $0.06 \pm 0.002$ & $0.04 \pm 0.01$ \\
\hline 50 & Jember & $8.87 \pm 1.51$ & $28.00 \pm 0.29$ & $2.17 \pm 0.05$ & $0.097 \pm 0.003$ & $0.11 \pm 0.02$ \\
\hline 51 & Bangkalan & $11.73 \pm 1.46$ & $15.99 \pm 0.28$ & $0.91 \pm 0.02$ & $0.109 \pm 0.003$ & $0.03 \pm 0.01$ \\
\hline 52 & Pasuruan & $17.89 \pm 1.76$ & $24.22 \pm 0.31$ & $0.85 \pm 0.02$ & $0.036 \pm 0.002$ & $0.03 \pm 0.01$ \\
\hline 53 & Surabaya & $18.02 \pm 1.94$ & $19.24 \pm 0.34$ & $0.86 \pm 0.02$ & $0.107 \pm 0.004$ & $0.12 \pm 0.01$ \\
\hline 54 & Situbondo & $31.13 \pm 1.97$ & $20.19 \pm 0.31$ & $0.77 \pm 0.02$ & $0.111 \pm 0.003$ & $0.32 \pm 0.03$ \\
\hline 55 & Magetan & $6.06 \pm 1.62$ & $28.60 \pm 0.11$ & $0.06 \pm 0.02$ & $0.113 \pm 0.003$ & $0.08 \pm 0.04$ \\
\hline 56 & Trenggalek & $8.68 \pm 1.59$ & $20.55 \pm 0.21$ & $0.06 \pm 0.01$ & $0.092 \pm 0.003$ & $0.03 \pm 0.01$ \\
\hline 57 & Banyuwangi & $6.44 \pm 1.00$ & $23.07 \pm 0.23$ & $0.02 \pm 0.02$ & $0.091 \pm 0.003$ & $0.05 \pm 0.02$ \\
\hline 58 & Ngawi & $10.29 \pm 2.27$ & $14.66 \pm 0.29$ & $>0.02$ & $0.095 \pm 0.004$ & $0.13 \pm 0.03$ \\
\hline 59 & Kediri & $60.91 \pm 4.07$ & $18.52 \pm 0.36$ & $>0.02$ & $0.126 \pm 0.005$ & $0.09 \pm 0.03$ \\
\hline 60 & Ponorogo & $15.65 \pm 2.12$ & $11.94 \pm 0.28$ & $0.05 \pm 0.02$ & $0.105 \pm 0.005$ & $0.21 \pm 0.03$ \\
\hline 61 & Probolinggo & $22.67 \pm 2.82$ & $17.91 \pm 0.21$ & $0.02 \pm 0.01$ & $0.088 \pm 0.004$ & $0.22 \pm 0.03$ \\
\hline 62 & Madiun & $6.69 \pm 1.30$ & $14.28 \pm 0.17$ & $>0.02$ & $0.071 \pm 0.003$ & $0.12 \pm 0.01$ \\
\hline $6 \overline{3}$ & Malang & $5.36 \pm 1.08$ & $15.23 \pm 0.15$ & $>0.02$ & $0.065 \pm 0.003$ & $0.03 \pm 0.01$ \\
\hline 64 & Pacitan & $7.34 \pm 1.21$ & $15.74 \pm 0.17$ & $0.08 \pm 0.02$ & $0.076 \pm 0.003$ & $0.09 \pm 0.01$ \\
\hline 65 & Sampang & $25.77 \pm 1.82$ & $23.33 \pm 0.22$ & $0.07 \pm 0.02$ & $0.083 \pm 0.004$ & $0.13 \pm 0.02$ \\
\hline 66 & Blitar & $8.61 \pm 1.13$ & $16.29 \pm 0.15$ & $0.05 \pm 0.02$ & $0.069 \pm 0.003$ & $0.09 \pm 0.01$ \\
\hline 67 & Bondowoso & $6.63 \pm 1.24$ & $16.59 \pm 0.17$ & $0.06 \pm 0.02$ & $0.062 \pm 0.003$ & $0.03 \pm 0.01$ \\
\hline 68 & Lumajang & $11.50 \pm 1.38$ & $11.49 \pm 0.13$ & $0.04 \pm 0.01$ & $0.074 \pm 0.003$ & $0.07 \pm 0.01$ \\
\hline & Mean & 13.50 & 17.85 & 0.33 & 0.08 & $0 . \overline{10}$ \\
\hline & Range & $4.62-60.91$ & $11.07-28.60$ & $0.02-2.71$ & $0.05-0.13$ & $0.03-0.32$ \\
\hline
\end{tabular}




$$
\text { Conc. of Elements }=\frac{A_{0 s p l}}{A_{0 s t d}} \times \frac{W_{s t d}}{W_{s p l}}
$$

Estimated Daily Intake of Rice and its contribution to $R D A$. The daily intake of each elements is a function of the amount of the element contain in food and the amount of the food that is being consumed daily. So, the estimated daily intake (EDI) depends on the element concentration and ingestion/consumption rate of the food. The EDI was determined using the following equation $(17,18)$.

$E D I=M C \times F C R$

Where $\mathrm{MC}$ is element concentration in food samples $(\mathrm{mg} / \mathrm{kg}$ in wet basis) and FCR represent the average of food consumption rate per day. For the calculation on this research, the rice consumption rate was $127.4 \mathrm{~kg} /$ person/year, therefore daily consumption rate of rice was $0.394 \mathrm{~kg} /$ person/d (19).

\section{RESULTS AND DISCUSSION}

\section{Minerals composition in white rice}

The element concentrations obtained from measurement were in dry mass basis. The elements concentrations of the samples must be converted to wet mass basis to calculate the contribution to the value of recommended dietary allowance by determining the water content of each samples. The water content of white rices obtained in the range of 9.6-16.5\% with average value was $13.0 \pm 1.3 \%$. The concentration of essential minerals in about 89 white rice samples (all in fresh weight) from Java island were presented in Table 2. The concentrations of $\mathrm{Co}, \mathrm{Cr}, \mathrm{Fe}, \mathrm{Se}$, and $\mathrm{Zn}$ were observed.

The results showed that the order of the mean concentrations of element in rice samples was $\mathrm{Zn}>\mathrm{Fe}>$ $\mathrm{Se}>\mathrm{Cr}>\mathrm{Co}$. The finding that rices contain more $\mathrm{Zn}$ than Fe was similar to those found in Thailand where rice is also their staple food by Srinattakul, 2014. It was found that the mean of $\mathrm{Zn}$ and $\mathrm{Fe}$ consentrations in their rice was $27 \mathrm{mg} / \mathrm{kg}$ and $7.98 \mathrm{mg} / \mathrm{kg}$ respectively (16). But in this study Zinc showed lower concentration while Fe has higher concentration compared to the result obtained by Srinattakul (16). Its also has lower concentration of $\mathrm{Zn}$ compared to the results found by Seeprasert, 2017 (25.4-29.8 mg/kg) and Co concentration as well $(0.15 \mathrm{mg} / \mathrm{kg})$ (2). But somewhat the results of Se, $\mathrm{Cr}$, and Co concentration of rice in this study showed similar result as in Jamaica (0.108, 0.08 and $0.097 \mathrm{mg} /$ $\mathrm{kg})(20)$. The results obtained were also have similar results with rice from Saudi Arabia $(1.9-55.1 \mathrm{mg} / \mathrm{kg}$ $\mathrm{Fe}, \quad 1.15-13.5 \mathrm{mg} / \mathrm{kg} \mathrm{Zn}, \quad 0.007-0.574 \mathrm{mg} / \mathrm{kg}$ Se, $0.01-0.184 \mathrm{mg} / \mathrm{kg} \mathrm{Cr}$ and $0.001-0.118 \mathrm{mg} / \mathrm{kg} \mathrm{Co})$ (11). From the previous study of Fe and Zn concentrations of Rices in Indonesia conducted by Mulyaningsih (5) and Rohaeni (6), it was showed that the Fe and Zn concentration most likely below $50 \mathrm{mg} / \mathrm{kg}$ as mentioned by Mulyaningsih (5) and have similar mean concentration of $\mathrm{Fe}$ and lower mean of Zinc concentration with results found by Rohaeni (11.25 and $22.89 \mathrm{mg} / \mathrm{kg}$ respectively (6). From the range of data showed that amounts of minerals were varied due species of rice and
Table 4. The estimation of daily nutrient intake (EDI) and contribution to RDA.

\begin{tabular}{ccccc}
\hline Elements & $\begin{array}{c}\text { Mean } \\
(\mathrm{mg} / \mathrm{kg})\end{array}$ & $\begin{array}{c}\text { Cons. Rate } \\
(\mathrm{kg} / \mathrm{d})\end{array}$ & $\begin{array}{c}\text { EDI } \\
(\mathrm{mg} / \mathrm{d})\end{array}$ & $\%$ RDA \\
\hline Co & 0.08 & & 0.03 & $61(\% \mathrm{UL})$ \\
$\mathrm{Cr}$ & 0.16 & & 0.06 & 158 \\
$\mathrm{Fe}$ & 10.8 & 0.349 & 3.76 & 47 \\
$\mathrm{Se}$ & 0.24 & & 0.08 & 153 \\
$\mathrm{Zn}$ & 16.9 & & 5.92 & 53.8 \\
\hline
\end{tabular}

many factors. The data showed that amounts of minerals and toxic elements were different even though they were same species. Table 3 shows the variation within the element concentration obtained from the 68 cities/ districts in Java island.

As can be seen in Table 3, the concentration of Fe, Zn, Se, Co and Cr shown quite variability. The table generally described that variability of Fe and Zn has similar pattern, but differ with Se. It seems that Se has variations not as much as $\mathrm{Fe}$ and $\mathrm{Zn}$ have. Selenium in rices of Java Island have same level of range concentration except from some certain areas. Most of the element showed highest mean concentration of $\mathrm{Fe}$ and Se were lied in East Java province, while the highest of $\mathrm{Zn}$ mean concentration was from Jakarta province. Central Java was tended to have lower concentration of most elements observed in this study. For $\mathrm{Zn}$ concentration in Rices, the lowest concentration was found in Boyolali, while for $\mathrm{Fe}$, the lowest concentration was found in Klaten and Tasikmalaya since the rices from these areas were below the detection limit. Selenium was foun in very small amount of concentration in rices, but many of them were able to quantified by NAA. In several cities, the $\mathrm{Cr}$ concentration in their rices showed high concentrations such as in Karawang and Blora. These finding should be further investigated since these values are exceeded the safety range recommended by The Committee on Dietary Allowance, Food and Nutrition of National Research, 0.05 to $0.2 \mathrm{mg} / \mathrm{d}$ (21). The concentration of minerals in rices, since it comes from plants, are strongly contributed to the soil conditions and how they were cultivated. Those variations are attributed to many factors such as the mineral composition of the soil, soil type, fertilizers, agricultural chemicals (herbicides, fungicides, wood preservatives, insecticides, rodenticides and sheep-dips) $(11,22)$, cultivar of plant, weather conditions during the growth, and the state of plant maturity at harvest (23). Furthermore, those variations are also affected by soil $\mathrm{pH}$, cation exchange capacity, soil texture, and the interaction of soil plant root microbes which play important roles in regulating movement from soil to the edible parts of plant. Additionally, different metal species in different forms have differ abilities to migrate from the soil through the plant parts and avail itself for consumption. This ability, represented by the bioconcentration factor, also influences the concentration of the elements in rice (2). Additional 
data of soil where they were cultivated should be needed to further examine the coorelation of elements content in rice with its origin areas.

Estimation daily nutrient intake and contribution to the recommended dietary allowances

In assessing the daily intake, the mean concentration of each element in rice was multiplied by consumption rate for Indonesian people. The consumption rate of rices is $0.349 \mathrm{~kg} / \mathrm{d}$. The results of estimated daily intake of trace elements obtained from the calculation is then compared to that of Recommended Dietary Allowance Value (RDA). RDA is the average daily intake level that is sufficient to meet the nutrient requirements of nearly all (97-98\%) healthy individuals in a particular life stage and gender group and it is commonly use as a standard value in assessing the adequacy of daily intake (24). The results of estimated daily intake of trace elements in rice and their constributions to Recommended Dietary Allowance value are presented in Table 4 .

It can be seen in Table 4 , that rice gives significant contribution to RDA values. Rice was the stapple food that widely consumed in Indonesia. The food habits of Indonesia people, not least in Java Island, mostly consist of carbohydrate and it explains the large contribution of rice to the trace element daily intake for inhabitant in Java Island. For Cobalt, there is no determined of RDA value, so the Upper Level Intake (UL) was taken. Table 3 showed that the daily intakes of $\mathrm{Cr}$ in rice were slightly exceeded its RDA value, but it is still in the safety range recommended by The Committee on Dietary Allowance, Food and Nutrition of National Research, 0.05 to $0.2 \mathrm{mg} / \mathrm{d}(21)$. While contribution of rice to $\mathrm{Fe}$ (male) and $\mathrm{Zn}$ (male) RDA values are slightly below, but if compared to the Fe RDA value for female, rice gives contribution only $21 \%$. RDA values for the Fe element is recommended for adult males of $8 \mathrm{mg} / \mathrm{d}$ and females mature at about $18 \mathrm{mg} / \mathrm{d}$, because of the amount of iron loss in the female body higher than male due to menstrual period (25). Therefore, the RDA value of $\mathrm{Fe}$ for men and women, according to their need, are different. Table 3 was also shown that Se in rices gives significant sontributions to RDA values by the average of Java peoples. But it still needs more detailed information since there are still many regions in Java which has low selenium content in their rice due to the soil conditions, related with the topography area. This kind of research must be carried out comprehensively in the next future with consideration of isotope analysis to get origin database and will gain more detailed information in coorelation with characteristic topographic area. Eventhough it shown that rices can give significant contribution to fulfill Javanese people's daily intake on certain elements based on the RDA values, the combination of foods will provide balance nutrient which are needed by human body to maintain their physiological functions.

\section{CONCLUSION}

Assessment of mineral elements content in white rices that widely consumed by local inhabitans of Java Island has been carried out. As much as nine minerals
(2 major elements and 3 trace elements) were determined in 89 samples of white rice. It was found that the content of $\mathrm{Zn}$, Fe, Se, Co and $\mathrm{Cr}$ in rice generally corresponded with previously reported data in other countries. It was found that the elemental concentrations in rices from Java Island followed the order $\mathrm{Zn}>\mathrm{Fe}>$ $\mathrm{Se}>\mathrm{Cr}>\mathrm{Co}$. It also found that rices from East Java Province have higher concentrations of $\mathrm{Fe}$ and Se, while the highest mean of $\mathrm{Zn}$ concentration was found in the rices from Jakarta province. Cobalt concentration in rices showed similar mean concentration for all provinces in Java Island observed. Highest $\mathrm{Cr}$ concentration was found in the rice from Blora and Karawang that need further investigation. The daily intake of those elements in rices give significant contribution to their RDA values. Eventhough, rice is the main contributor of essential minerals intake, it is needed to be considered that a healthy diet is not just to fulfill the nutrition requirements but also should consist of a balanced varied diet.

\section{Disclosure of state of COI}

No conflicts of interest to be declared.

\section{Acknowledgments}

The authors would like to give acknowledgement to BATAN for the financial support, and for colleagues of PSTNT who gave contributions to this research.

\section{REFERENCES}

1) Aksu SK, Celyk G, Gucer S. 2014. Investigation of Trace Element Contents of Rice By ETAAS and ICP-MS. Adnan Menderes University," 4th AACD Congr. KuşadasıAYDIN, TURKEY. Proc. B 284 (June 2014): 1-4.

2) Seepraset P, Anurakpongsatorn P, Laoharojanaphand S, Busamongkol A. 2017. Instrumental neutron activation analysis to determine inorganic elements in paddy soil and rice and evaluate bioconcentration factors in rice. Agric Nat Resour 51(3): 154-157.

3) Mataveli LRV, Buzzo ML, Juncioni de Arauz L, Carvalho MFH, Arakaki EEK, Matsuzaki R, Tigle P. 2016. Total arsenic, cadmium, and lead determination in Brazilian rice samples using ICP-MS. J Anal Methods Chem 2016: 1-9. Article ID 3968786.

4) Oko AO, Ugwu SI. 2011. The proximate and mineral compositions of five major rice varieties in Abakaliki, South-Eastern Nigeria. Int $J$ Plant Physiol Biochem 3(February): 25-27.

5) Mulyaningsih RT. 2009. The concentration of $\mathrm{Fe}$ and $\mathrm{Zn}$ in foodstuff of agriculture, husbandry and fishery determined by k0-NAA. Jurnal Sains dan Teknologi Nuklir Indonesia $\mathbf{X}(2)$ : 71-80 (in Indonesia).

6) Rohaeni WR, Supriadi E, Susanto U, Rohsadi TD. 2016. $\mathrm{Fe}$ and Zn content of Brown Rice and Milled Rice on Brown Planthopper Tolerant Rice Lines. Jurnal Ilmu Pertanian Indonesia 21(3): 172-176 (in Indonesia).

7) Alzahrani HR 2017. Determination of macro, essential trace elements, toxic heavy metal concentrations, crude oil extracts and ash composition from Saudi Arabian fruits and vegetables having medicinal values. J Chem 10(7): 906-913.

8) Hamid A, El-samad MA, Soliman NF, Hanafi HA. 2017. Detection of minor and trace elements in powdered 
milk. Integr Med Res 11(1): 186-195.

9) Anastácio M, Santos APM, Aschner M, Mateus L. 2018. Determination of trace metals in fruit juices in the Portuguese market. Toxicol Rep 5(January): 434-439.

10) Syahfitri WYN, Damastuti E, Adventini N, Atmodjo DPD, Kusmartini I, Kurniawati S, Lestiani DD, Santoso M. 2018. Essential minerals of rice in West Java Indonesia and its daily intake estimation. Atom Indones 44(3): 155.

11) Shraim AM. 2017. Rice is a potential dietary source of not only arsenic but also other toxic elements like lead and chromium. J Chem 10: S3434-S3443.

12) Oko AO, Ubi BE, Efisue AA, Dambaba N. 2012. Comparative analysis of the chemical nutrient composition of selected local and newly introduced rice varieties grown in Ebonyi State of Nigeria. Int J Agric For 2(2): 16-23.

13) Abbas A, Murtaza S, Aslam F, Khawar A. 2011. Effect of processing on nutritional value of rice (Oryza sativa). World J Med Sci 6(2): 68-73.

14) Emumejaye K. 2014. Heavy and trace elements in some brands of rice consumed in Delta State, Nigeria. IOSR J Appl Phys 6(2): 01-05.

15) Ozbek N, Tinas H, Atespare AE. 2019. A procedure for the determination of trace metals in rice varieties using microwave induced plasma atomic emission spectrometry. Microchem J 14(July2018): 474-478.

16) Srinuttrakul W, Busamongkol A. 2014. Elemental analysis of brown rice by inductively coupled plasma atomic emission spectrometry and instrumental neutron activation analysis. Energy Procedia 56C: 85-91.

17) Sultana MS, Rana S, Yamazaki S, Aono T, Yoshida S, 2017. Health risk assessment for carcinogenic and noncarcinogenic heavy metal exposures from vegetables and fruits of Bangladesh. Cogent Environ Sci 3(1): 1-17.

18) Bortey-sam N, et al. 2015. Ecotoxicology and Environmental Safety Human health risks from metals and metalloid via consumption of food animals near gold mines in Tarkwa, Ghana Estimation of the daily intakes and target hazard quotients (THQs). Ecotoxicol Environ Saf 111: $160-167$.

19) GRiSP (Global Rice Science Partnership). 2013. Rice almanac, 4th edition. Los Baños (Philippines): International Rice Research Institute. 283 p.

20) Antoine JMR, Fung LAH, Grant CN, Dennis HT, Lalor GC. 2012. Dietary intake of Minerals and Trace Elements in Rice on Jamaican market. J Food Comp Anal 26: 111-121.

21) Biego G, Joyeux M, Hartmann P, Debry G. 1998. Daily intake of essential minerals and metaliic micropollutants from foods in France. Sci Total Environ 217(1-2):
27-36.

22) Parengam M, Judprasong K, Srianujata S, Jittinandana S. 2010. Journal of Food Composition and Analysis Study of nutrients and toxic minerals in rice and legumes by instrumental neutron activation analysis and graphite furnace atomic absorption spectrophotometry. J Food Compos Anal 23(4): 340-345.

23) Bressy FC, Brito GB, Barbosa IS, Teixeira LSG, Graças M, Korn A. 2013. Determination of trace element concentrations in tomato samples at different stages of maturation by ICP OES and ICP-MS following microwave-assisted digestion. Microchem J 109: 145-149.

24) Damastuti E, Syahfitri WYN, Santoso M, Lestiani DD. 2012. Assessment of trace element daily intake based on consumption rate of foodstuffs in Bandung City. Atom Indones 1(1): 29-34.

25) National Academy of Sciences, Dietary DRI Reference Intakes. Washinton DC: The National Academies Press, 2006.

26) Aksu SK, Celyk G, Gucer S. 2004. "Investigation of Trace Element Contents of Rice By ETAAS and ICP-MS, Adnan Menderes University," 4th AACD Congr. Kuşadası-AYDIN, TURKEY. Proc B 284: 1-4.

27) Seeprasert P, Anurakpongsatorn P, Laoharojanaphand S, Busamongkol A. 2017. Instrumental neutron activation analysis to determine inorganic elements in paddy soil and rice and evaluate bioconcentration factors in rice. Agric Nat Resour 51(3): 154-157.

28) Mataveli LRV, et al. 2016. Total Arsenic, Cadmium, and Lead Determination in Brazilian Rice Samples Using ICP-MS. J Anal Methods Chem 2016.

29) Oko AO, Ugwu SI. 2011. The proximate and mineral compositions of five major rice varieties in Abakaliki, South-Eastern Nigeria. Int J Plant Physiol Biochem 3(February): 25-27.

30) Sultana MS, Rana S, Yamazaki S, Aono T, Yoshida S. 2017. Health risk assessment for carcinogenic and non-carcinogenic heavy metal exposures from vegetables and fruits of Bangladesh. Cogent Environ Sci 3(1): $1-17$.

31) Hu J, Wu F, Wu S, Cao Z, Lin X, Wong MH. 2013. Bioaccessibility, dietary exposure and human risk assessment of heavy metals from market vegetables in Hong Kong revealed with an in vitro gastrointestinal model. Chemosphere 91(4): 455-461.

32) Bressy FC, Brito GB, Barbosa IS, Teixeira LSG, Graças M, Korn A. 2013. Determination of trace element concentrations in tomato samples at different stages of maturation by ICP OES and ICP-MS following microwave-assisted digestion. Microchem J 109: 145-149. 